\title{
Gamification during Covid-19: Promoting active learning and motivation in higher education
}

\author{
Elvira G. Rincon-Flores, Brenda N. Santos-Guevara
}

Institute for the Future of Education, Center for Professional Development and Educational Partnership, Tecnologico de Monterrey

\begin{abstract}
Virtual teaching modalities urgently implemented during the Covid-19 pandemic require strategies to motivate students to participate actively in higher education. Our study found that gamification using a reward-based system is a strategy that can improve the educational experience under exceptional circumstances. This article reports the results of two gamified undergraduate courses (Calculus and Development of Transversal Competencies) designed with a reward system. The results derived from analyses of online surveys, the final grades, and their correlations revealed that gamification helped motivate students to participate actively and improved their academic performance, in a setting where the mode of instruction was remote, synchronous, and online. From the results we conclude that gamification favours the relationship between attention, participation, and performance, while promoting the humanisation of virtual environments created during academic confinement.
\end{abstract}

\section{Implications for practice or policy:}

- Gamification using a reward-based system promoted active class participation and improved student performance after the transition from face-to-face to virtual instruction required as a result of the global pandemic.

- Systemic recognition in a reward-based system improved the participants' emotional states, reducing their anxiety and the feeling of isolation caused by the pandemic, and leading to student engagement with .

- Gamification works as an accompaniment for students to help the increasement of teacher-student and student-student interactions.

Keywords: gamification, game rewards, motivation, innovative education, academic confinement

\section{Introduction}

The Covid-19 pandemic has caused terrible damage worldwide, not only to people's health but also to economies, politics, and society (Arnove, 2020). This situation impacted universities as some countries closed facilities, forcing instruction to migrate to the online mode almost overnight. The abrupt changes caused by the pandemic have significantly affected students at all educational levels. Under these circumstances, educators must develop the best educational environments for meaningful learning to remedy the academic lag from the Covid-19 pandemic (American Psychological Association [APA], 2020; Daniel, 2020). With this in mind, we transferred the gamification strategy used in our face-to-face instructional modality to a synchronous online environment using the Zoom platform. The purpose of this article is to show how gamification with a reward-based system has played an essential role during the Covid-19 pandemic to attract student attention, engagement, and motivation in the teaching-learning process. Additionally, without knowing when and how students and teachers will return to the classroom, we developed this proposal as an alternative for teachers and researchers who seek to improve students' well-being as they take their courses.

\section{Literature review}

\section{Gamification for active learning}

Recent educational trends reveal that educators favour active learning, where the student is the center of the learning process (Tharayil et al., 2018). Thus, several studies argue that active learning moves students from memorisation to a more meaningful learning experience (Aji \& Khan, 2019). Freeman et al. (2014) show that students exposed to active learning have less risk of failing or dropping out than students who take classes under traditional instruction. Students tend to get better grades when teachers avoid 
distractions, set clear learning goals, and provide opportunities for interaction in safe spaces for students to ask questions (Lagubeau et al., 2019). Although designed to improve learning, teaching methodologies alone, such as problem-based learning, collaborative learning, and project-based learning (Davis \& McPartland, 2012), do not end apathy, lack of commitment, and the inattention of students (Gomez-Chacón, 2000; Rincon-Flores, Lopez-Camacho et al., 2020). The intended improvements must align with methodologies that involve students' engagement to educational strategies (Rojas-López et al., 2019).

According to Hamari et al. (2016), immersing students in activities promotes their engagement with learning. For other authors (Gruman et al., 2010; Looyestyn et al., 2017), commitment (engagement) is the amount of energy applied to actions and tasks' completion. Skinner and Belmont (1993) define engagement as the passion for developing and completing assigned learning activities. In other words, positive impulses drive the accomplishment of a task.

Moreover, students can have three types of participation: behavioural, cognitive, and emotional (Fredricks et al., 2004). Behavioural participation in a class results from the student's positive attitude. Cognitive participation involves the willingness to think and understand a topic or concept. It requires self-regulation (Deci \& Ryan, 2008). Finally, with emotional participation, the student reacts to the feelings experienced in class. Emotional participation displays are happiness, apathy, anxiety, interest, or boredom.

In the 1990s, Csikszentmihalyi (1990) developed the flow theory, where the student is absorbed by doing some activity that they enjoy. Using this approach, Csikszentmihalyi found that people immersed in activity experience joy and a sense of success (Admiraal et al., 2011). Therefore, this flow leads to engagement with learning and a positive learning experience (Hamari \& Koivisto, 2015; Hou \& Li, 2014; Sailer et al., 2017; Tsai et al., 2016). Attention is the ability to stay focused on an object or thought for a specified period (Korving et al., 2016). Posner et al. (1980) describe three attention processes: alertness, spatial orientation, and executive attention. In an adult, achieving an efficient state of attention implies developing and coordinating perceptions, strengthening neural connections, and interacting supported by memory processes (Amso \& Scerif, 2015). Through didactic strategies, it is possible to trigger commitment. Additionally, well-managed steadfastness and flow can drive intrinsic or extrinsic motivation, which correlates with autonomy and external regulation (Alsawaier, 2018; Deci \& Ryan, 2008; Topîrceanu, 2017). Our reflections on the gamification strategy we employed align with these ideas. When developing a class, gamification is an effective educational strategy to promote student attention and engagement.

Gamification also enhances active learning. Studies worldwide show that gamification is a strategy to increase student participation (Borras-Gene et al., 2016; Freudmann \& Bakamitsos, 2014; Hamari \& Koivisto, 2015; Kyewski \& Krämer, 2018). It is used in business (Herzig et al., 2015; Robson et al., 2015; Saputro et al., 2019), government (Hassan \& Hamari, 2020), health (Buchem et al., 2015; Garett \& Young, 2019; Magaña-Valladares et al., 2018), and education (Domínguez et al., 2013; Hanus \& Fox, 2015; Rincon-Flores, Mena et al., 2020; Rojas-López \& Rincon-Flores, 2018; Santos-Guevara \& Rincon-Flores, 2020). Gamification employs game elements in contexts that are not typically games (Deterding, 2015) to boost intrinsic and extrinsic motivation in various ways. Extrinsic motivation can result from a reward system, while challenges produce intrinsic motivation (Rincon-Flores et al., 2018; Rojas-López et al., 2019; Surendeleg et al., 2014 ). Thus, game elements and experiences designed in the learning methodologies in any field of study define gamification. The student also develops transversal competencies and attitudes through gamification, such as collaboration, self-regulated learning, and creativity (Caponeto et al., 2014; Dichev \& Dicheva, 2017). In gamified learning, rules, emotions, and social roles are part of the experience (Lee \& Hammer, 2011) and are essential aspects of the educational process.

\section{Rewards for the win!}

While self-regulation theory explains the correlations of intrinsic motivation, autonomy, competence, and socialisation (Deci \& Ryan, 2008), extrinsic motivation defines external regulation, introspection, identification, and integration (Topîrceanu, 2017). Engagement and flow influence motivation, both, intrinsic and extrinsic, since behavioral changes are triggered when various educational strategies are designed to generate commitment (Alsawaier, 2018). Therefore, reward-based systems in gamified classes play a vital role in player motivation to act and become engaged with learning (Rodríguez \& Santiago, 2015; Werbach \& Hunter, 2012). Reward-based systems are designed to recognise participants' achievements through tangible or virtual goods, for example, Starbucks' accumulated stars that customers 
can exchange for prizes (Xin et al., 2018). Thus, participants seek a benefit after completing a specific task or activity because they are motivated by a tangible gift, treat, or competition (Frost et al., 2015; Park et al., 2019). The rewards or changes in the participants' attitudes (Zimmerling et al., 2019) can be internally satisfying (intrinsic motivation) or practical (extrinsic motivation) (Morschheuser et al., 2019).

In this research, understanding that rewards motivate students to participate, we created a reward system within a gamification resource. We determined the appropriate award timing, the type of reward, and the method to obtain it (Kwiatek \& Thanasi-Boce, 2019). According to Schöbel and Söllner (2014), there are four types of rewards: individual, collaborative, competitive, and competitive-collaborative. Thus, a person may be motivated by a sense of autonomy, a relationship, or achievement of a competency (Frost et al., 2015), emphasising the relevance of the game narrative (Iain et al., 2019).

The type of reward most used in gamification is the collaborative-competitive type (Schöbel \& Söllner, 2014), where it is possible to accumulate points through specific incentives or reward structures (Zimmerling et al., 2019). A tangible reward is the most inspiring motive for some users, while a real but achievable challenge is more satisfying for others (Heninger et al., 2019). However, rewards are not the only motivator. All the experiences involved in gamification are motivating.

Furthermore, motivational factors can be classified into three categories, identifiable achievement, social interaction, and immersion (Smeddinck et al., 2019), which all determine a player's level of participation. This classification gives a feeling of progress and better (mechanical) performance since it is a challenge that involves socialisation. The timing of the reward plays a significant role in the intensity of extrinsic motivation (Plangger et al., 2019).

Under behaviour theory, the participant's motivation depends on the type of incentives and the frequency of obtaining rewards, whether tangible or intangible (Smeddinck et al., 2019). The rewards granted, consider progress and expected or desired behaviour. All these affect intrinsic motivation. According to the self-determination theory (Lefers \& Birkenkrahe, 2016), external motivation becomes a factor that increases internal motivation, and vice versa. We can also say that motivation is transformed into action when the participants accept being part of the game's dynamics and mechanics to demonstrate their ability, autonomy, relationship, and competence in an environment conducive to quality learning (Frost et al., 2015).

In education, one of the representative mechanisms of gamification is the leaderboard, that shows each participating member's scores (Jin et al., 2016). The leaderboard and avatars exemplify the dynamic way in which participants choose an anonymous identity for their achievements, the relationship and competency factors, seen as a motivational requirement (Smeddink et al., 2019). However, Kocadere and Çağlar (2018) argue that the leaderboard's purpose is to motivate the killer players, while the badges motivate the winners. Unlocking content in a game (moving to the next level, for example) corresponds to explorers, while both gifts and teamwork attract socialisers. Therefore, an effective reward system must incentivise different types of players according to their classifications.

Gamification offers an opportunity for broad participation and enjoyment of the learning experience (Tan \& Hew, 2016) because it can be developed as a phone app (Wu, 2018) or for the online computer, thus, attractively changing the students' flow (Laato et al., 2020). Gamification combines content, technology, and interaction while facilitating remote distance learning (Observatory on Educational Innovation, 2020). The gamification proposal of this study is summarised in Figure 1. 


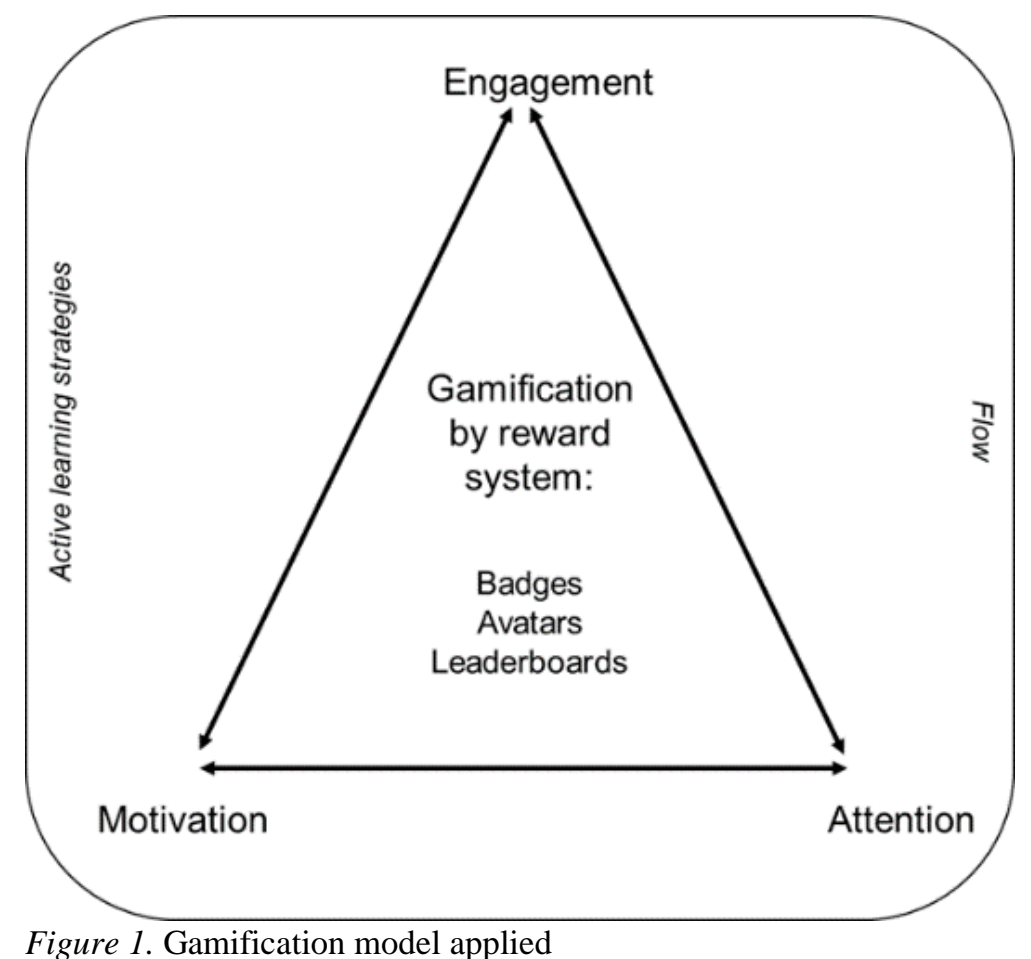

Figure 1. Gamification model applied

The gamification model that we proposed in this study was based on a reward system that included badges, avatars, and a leaderboard designed to promote the attention, motivation, and continuous engagement of students in an active learning scenario that maintained the flow to get the best performance, even beyond grades, applied in a context of academic confinement. It is important to note that this model can be replicated in various disciplines and learning environments.

\section{Methods and procedures}

\section{Description of the reward system}

During the spring semester (February to June 2020), we applied gamification in Calculus for Engineering and Development of Transversal Competencies, two undergraduate courses at Tecnologico de Monterrey. In the first subject, we made a narrative of superheroes to recognise knowledge, attitudes, and values that fundamentally comprise the integral development of our university graduates. For this course, six math badges were enabled for earning points that could be redeemed in each evaluation period (every 5 weeks), up to a maximum of 10 points. If a student accumulated more than 10 points, these could be saved for the next evaluation period. Each badge corresponded to a different number of redemption points. Table 1 shows the reward system.

Table 1

Description of the "Superpowers" reward system

\begin{tabular}{|c|c|c|}
\hline $\begin{array}{l}\text { Badge of } \\
\text { power }\end{array}$ & Description & Points \\
\hline & $\begin{array}{l}\text { Undergraduates earned the Flash badge when they answered a } \\
\text { challenging quick-response question. The goal was to attract } \\
\text { the attention of the class. }\end{array}$ & 1 \\
\hline & $\begin{array}{l}\text { Undergraduates earned the Stark badge when they answered a } \\
\text { more challenging question or placed first in a Kahoot. }\end{array}$ & 2 \\
\hline & $\begin{array}{l}\text { The Captain America badge recognised students who } \\
\text { performed their activities on time, well prepared, and correctly. } \\
\text { The goal was to acknowledge positive attitudes. }\end{array}$ & 1 \\
\hline
\end{tabular}




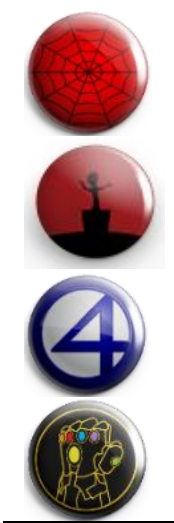

Spider badge recognised students' progress, for example, when they improved in a second assessment.

Groot badge recognised values, for example, when the teacher noticed that the student helped other classmates.

The Fantastic Four badge recognised students' collaborative work.

Thanos badge eliminates the badges won in an evaluation period.Its objective is to punish an academic failure or a disrespectful attitude with their peers or teacher.

Instead of taking class attendance (because connectivity issues inevitably occur in online instruction), we decided to recognise the assigned activities' content, presentation, and punctuality. Likewise, we decided to increase the number of questions to encourage participation and attention in synchronous classes (Flash and Stark badges) and more collaborative work, recognising the teams' performance (Fantastic Four badge). To participate in the reward system, the students selected an avatar to represent them, an image displayed on the leaderboard that was updated weekly. The avatar also had the purpose of hiding the students' identities to respect their privacy, only the teachers knew the identity of the participants. Figure 2 shows a partial image of one course leaderboard where we applied the reward system.

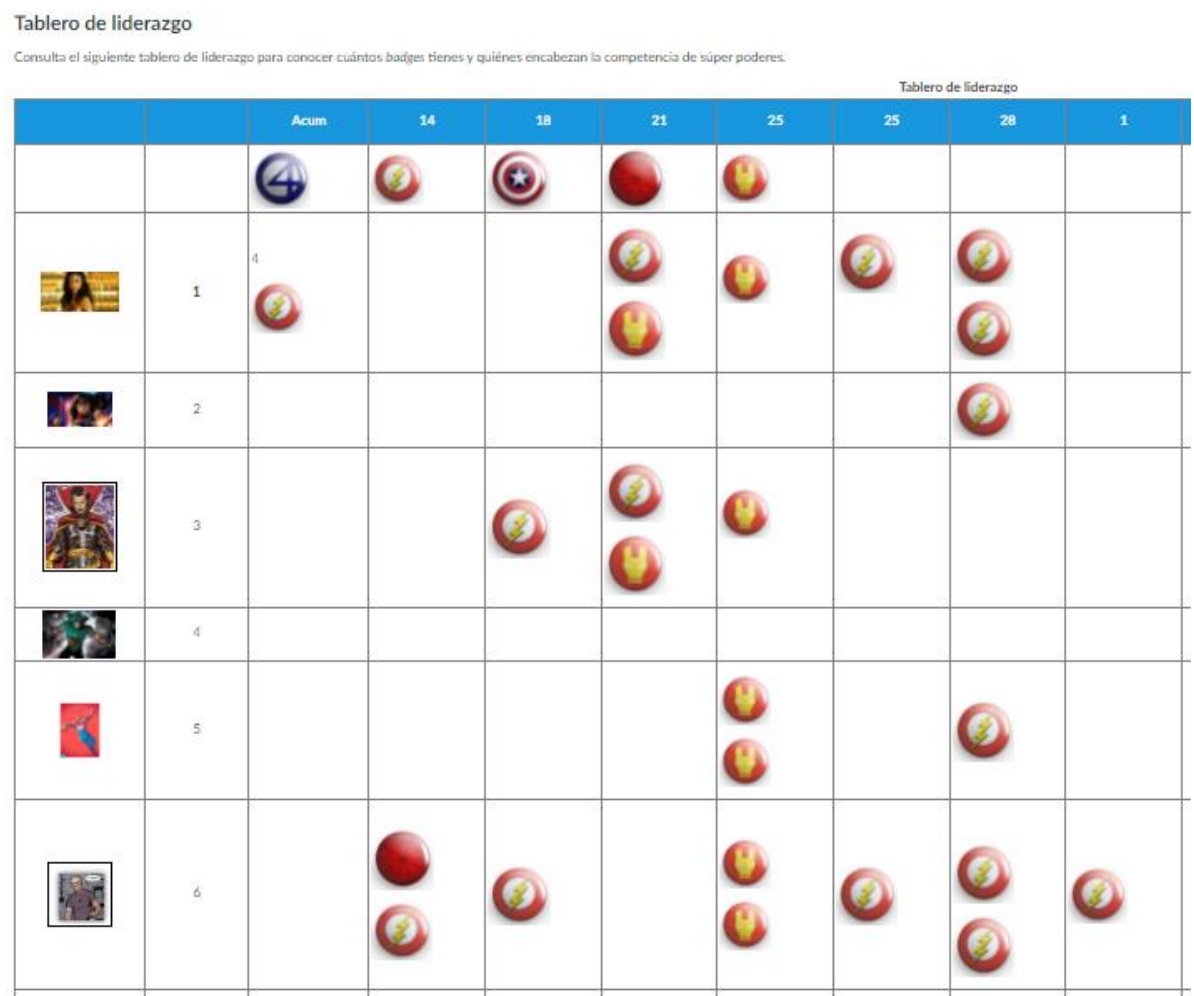

Figure 2. Partial image of the leaderboard

The reward system in the Development of Transversal Competencies course operated similarly to the Calculus course, the only difference being that the former seeks to prepare students for an internship, so its syllabus explained the recruitment processes and products, such as resume, interview preparation, and LinkedIn profile, among others. Students willing to participate submitted their avatars for anonymous display on the leaderboard. Seven different badges corresponded to specific course assignments (Table 2). This course had an outdoor challenge activity, named TecChallenge, in which students could get three kinds of badges through group voting (resilience, audacity, and realisation). During the pandemic, this activity was virtual, but it maintained the spirit of challenge and teamwork. The teacher assigned the other badges 
according to pre-established instructions and requirements. For example, for the Victory badge, students had to be in the first three positions on the LinkedIn group profile ranking, while the Networking badge needed evidence of contacting ex-alumni to increase their LinkedIn network. Perseverance was assigned to students who attended their classes and completed all the assignments. For this course, each badge represented 2 extra points toward the final grade on a scale from 0 to 100.

Table 2

Badge descriptions for the Development of Transversal Competencies course

\begin{tabular}{|c|c|c|}
\hline Badge & Description & Points \\
\hline & $\begin{array}{l}\text { The Victory badge represented a triumph. It might be awarded } \\
\text { for having accumulated the most points or outstanding } \\
\text { performance in Resume, LinkedIn 1, and LinkedIn } 2 \text {. }\end{array}$ & 2 \\
\hline & $\begin{array}{l}\text { Effective Communication badge was awarded when } \\
\text { communication was successful during the elevator pitch, email, } \\
\text { and mock interview activities. }\end{array}$ & 2 \\
\hline & $\begin{array}{l}\text { Networking badge was awarded when the student managed to } \\
\text { increase their network. }\end{array}$ & 2 \\
\hline & $\begin{array}{l}\text { Resilience badge was awarded when students participated in } \\
\text { collaborative activities with classmates. This badge could also } \\
\text { be awarded in the mock interview. }\end{array}$ & 2 \\
\hline & $\begin{array}{l}\text { Realisation badge was awarded when students showed their } \\
\text { hidden skills during the Tec Challenge. }\end{array}$ & 2 \\
\hline & $\begin{array}{l}\text { Audacity badge recognised when the student proposed and } \\
\text { carried out unusual activities to solve challenges if they did not } \\
\text { put their integrity and classmates at risk. }\end{array}$ & 2 \\
\hline & $\begin{array}{l}\text { Perseverance badge recognised class attendance and } \\
\text { completion of all the course assignments. }\end{array}$ & 2 \\
\hline
\end{tabular}

The leaderboard for this course was similar to the one shown in Figure 2. Participation in the reward system was voluntary. Those who decided not to participate were not affected. If students wanted to join later, they could do so at any time during the course.

\section{Research questions}

In this research, we used a mixed (Creswell, 2007; Creswell et al., 2003) and correlational methodological approach, where the qualitative results complemented the quantitative results. The following research questions guided us:

(1) To what extent did gamification with a reward-based system motivate students during academic confinement due to COVID-19?

(2) To what extent did gamification with a reward-based system improve students' attention and active participation during academic confinement due to COVID-19?

(3) To what extent did gamification with a reward-based system improve students' performance during academic confinement due to COVID-19?

We administered a Likert-type scale questionnaire (4 points) to the students in each course to answer the first research question. The questionnaire aslo included some open-ended questions that students voluntarily answered. Likewise, we administered a questionnaire with a Likert-type scale for the second research question, including some open questions. We established a correlation between the final grade with the number of badges that each student obtained. For this purpose, only the attention and active participation badges were used (Flash and Stark badges). For the third research question, we calculated the 
correlation between the total number of badges earned by students and their grades. In addition, we reviewed the results of the institutional evaluations of teachers' performances during the global pandemic.

\section{The sample}

The sample consisted of 57 students, 40 enrolled in Calculus and 17 in Development of Transversal Competencies. The ages of the undergraduate students ranged from 19 to 21 years old. Most were from different cities in Mexico and some from other Latin American countries.

\section{Research and analysis phases}

Figure 3 shows the research phases and the instruments and data collection techniques used. We implemented the rewards system during the academic semester, February to June 2020. At the end of each course, we applied a questionnaire with a Likert-type scale. This instrument also included some open questions about the impression that gamification made on the students in each course.

\section{REWARDS MECHANICS}

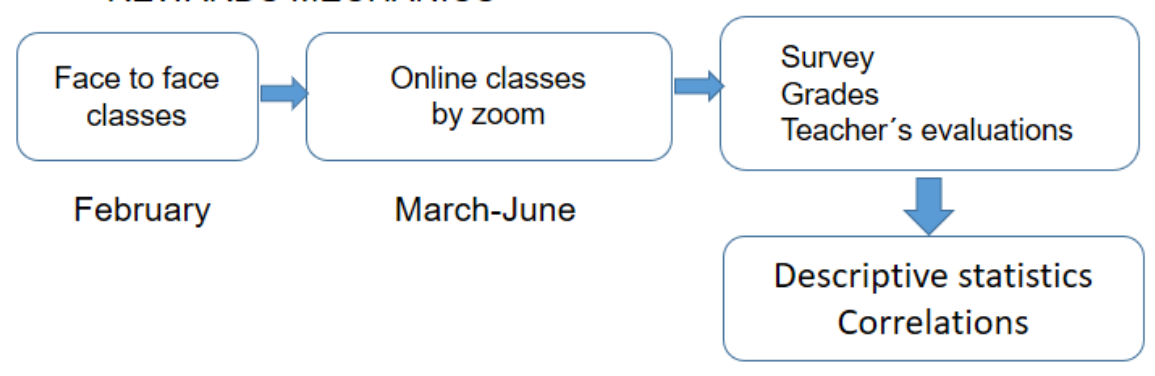

Figure 3. Research phases

In addition to the questionnaire, we considered the students' final grades. We counted the badges earned by each student to determine the correlation between the reward system and their academic performance. We also included teachers' evaluations, emphasising items related to gamification applied during the academic confinement. We processed all the data in Microsoft Excel for descriptive analysis, and we used SPSS software to calculate and analyse the correlations.

Particularly for the third research question, we complemented the analysis with the institutional evaluation of the professors, which all the university students use to evaluate their professors. This instrument also allows the students to assess the academic course challenge, have interactions with the professor, view procedures, and make other statements. This evaluation has 12 questions that students answer on a 0 to 100 scale at the end of the academic period. A centralised team processes the results. Teachers receive a report with the evaluation and comments from the students after registering the final grades. Results used in this research derive from the following questions:

a. About methodology and learning activities (providing clear and precise explanations, media, innovative techniques, and technological tools to facilitate and support my learning), the course was ...

b. About the intellectual challenge (motivation to deliver my highest effort for the quality of my learning and personal growth), the course was ...

c. Interactions with my professor during the academic confinement of the contingency have been ...

d. Statement about the ethical issues.

The information collected for the research was authorised by the students and the institution under the agreement that it would be used for research purposes and will maintain students' anonymity. 


\section{Results}

\section{Research question 1: To what extent did gamification with a reward-based system motivate students in the academic confinement due to COVID-19?}

We administered a questionnaire with a Likert-type scale to the students registered in both courses to answer this question. First, the students who took Calculus and then those enrolled in Development of Transversal Competencies are shown. Next, we discuss the results of some of the open-ended questions, followed by the teachers' evaluations.

\section{Results for students in the calculus class}

Forty students from the engineering degree program answered the questionnaire. Six women and 34 men ages 19 to 21 participated in the survey. The answers to the four questions are shown in Table 3.

Table 3

Class attendance, active participation, quality of homework, and positive emotions in calculus class

\begin{tabular}{|c|c|c|c|c|}
\hline Question & Totally agree & Agree & Disagree & $\begin{array}{c}\text { Totally } \\
\text { disagree }\end{array}$ \\
\hline $\begin{array}{l}\text { Did the reward system } \\
\text { motivate you to attend } \\
\text { classes? }\end{array}$ & $72 \%$ & $25 \%$ & $3 \%$ & $0 \%$ \\
\hline $\begin{array}{l}\text { Did the reward system } \\
\text { motivate you to take part in } \\
\text { the class? }\end{array}$ & $75 \%$ & $20 \%$ & $5 \%$ & $0 \%$ \\
\hline $\begin{array}{l}\text { Do you think that the reward } \\
\text { system motivates you to } \\
\text { improve the quality of your } \\
\text { homework? }\end{array}$ & $67 \%$ & $30 \%$ & $3 \%$ & $0 \%$ \\
\hline $\begin{array}{l}\text { When you earned a badge, } \\
\text { did you feel a positive } \\
\text { emotion? }\end{array}$ & $92 \%$ & $5 \%$ & $3 \%$ & $0 \%$ \\
\hline
\end{tabular}

The results indicated that $97 \%$ of the students who answered the questionnaire agreed that the rewards system helped them attend classes and improve their homework quality. In comparison, 95\% said that the system motivated them to participate in class.

\section{Badges the students liked the most}

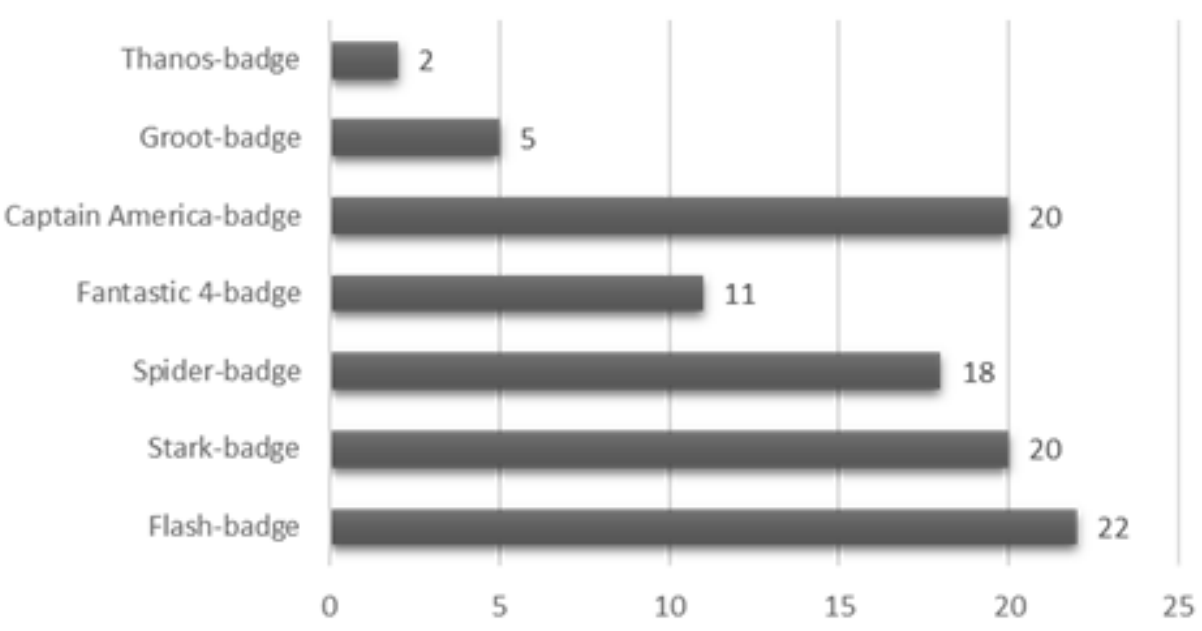

Figure 4. Badge occurrences 
Figure 4 shows how striking it was that the badges that students frequently obtained were the Flash badge and the Stark badge, which rewarded class participation. In second place was the Captain America badge, which recognised quality in homework and activities. Some of the students' opinions were:

- I loved the badges because they help you and motivate you to stay in class. It is a way of showing that you are progressing.

- For me, they were a new system that I had not seen in any other class, and it made it more challenging and exciting.

- The more challenging the question, the more I tried to do my best on the tasks. I also really like teamwork.

- They reward students with qualities that I consider essential.

The answers to the students' open questions are consistent with Table 3, which highlights that they agreed that gamification based on a reward system motivated their class participation and improved the quality of their assignments.

\section{Students enrolled in the Development of Transversal Competencies course}

Likewise, we also administered questionnaire with a Likert-type scale to measure students' satisfaction with the rewards mechanics. Eleven students (four women and seven men) completed this questionnaire (Table 4).

Table 4

Results in the Development of Transversal Competencies course

\begin{tabular}{lcccr}
\hline Question & Totally agree & Agree & Disagree & Totally disagree \\
\hline $\begin{array}{l}\text { Do you think the reward } \\
\text { system motivates you to }\end{array}$ & $50 \%$ & $50 \%$ & $0 \%$ & $0 \%$ \\
$\begin{array}{l}\text { participate and/or } \\
\text { complete course }\end{array}$ & & & & \\
$\begin{array}{l}\text { assignments? } \\
\begin{array}{l}\text { Do you think } \\
\text { gamification relates to } \\
\text { this course? }\end{array}\end{array}$ & $50 \%$ & $40 \%$ & $10 \%$ & $0 \%$ \\
\hline
\end{tabular}

The survey results indicated that the reward system offered advantages for students beyond entertainment, on Table 4 we can see that fifty percent of the students found gamification, specially reward system, was related to the course content. This indicated that the students appreciated gamification as a course content reinforcement, not only a "funny" way to improve their performance or get extra points.

Resilience was the students' favourite badge because it recognised their personal effort, mainly in virtual classes during the pandemic situation. The Resilience badge was attached to different assignments, such as the mock interview, which requires a willingness to accept feedback and pay attention to details on an interview. It also was earned through classmates' voting in the virtual TecChallenge session. Students voted for their peers according to their performance during the online session. It was common to see the same students awarded Resilience and Audacity, the latter being the second-favourite badge in this course (Figure $5)$. 


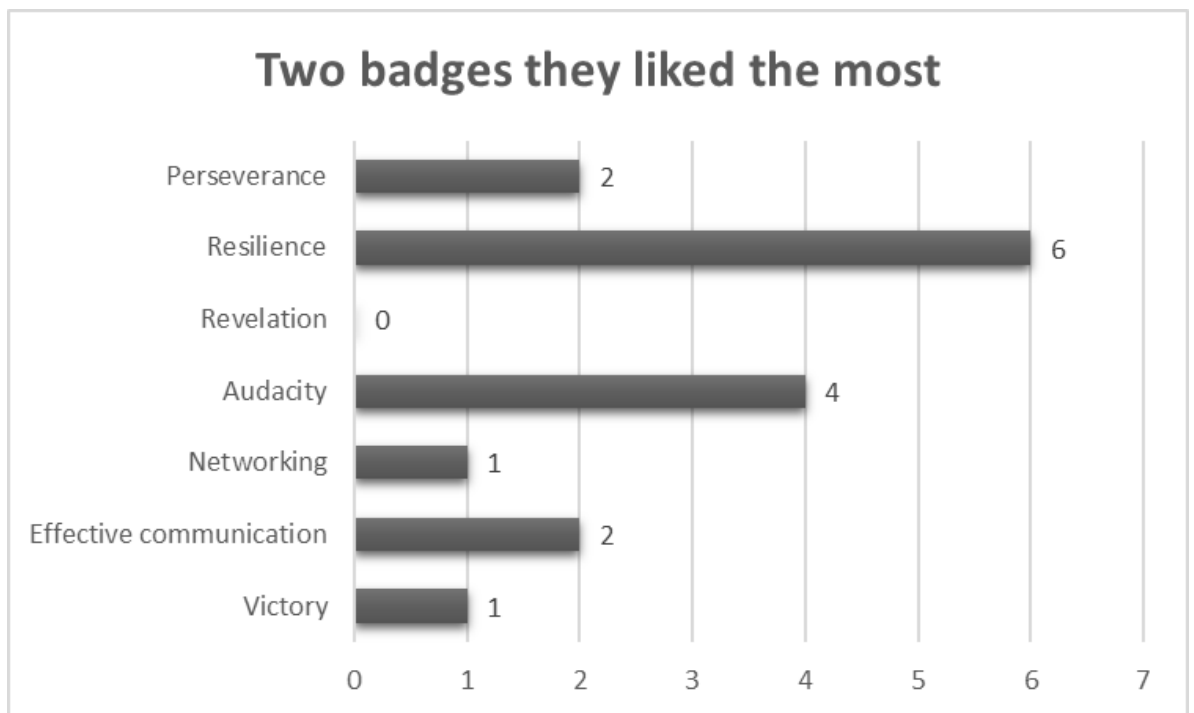

Figure 5. Students' favourite badges in the Development of Transversal Competencies course

One student specifically commented that the reward system inspired him to do a better job. Another student said that the best assignment was the one the Networking badge related to: using and improving their LinkedIn profile. This badge combined factors where students benefited from doing activities that help them get into the job market, something beyond traditional grade assignments. Thus, students did their assignments and took a step toward to getting an internship and becoming a professional.

When students were asked if they would add another badge, some mentioned competencies they would like to see reinforced through a badge. However, most of the students answered "none."

Research question 2: To what extent did gamification with a reward-based system improve students' attention and active participation during the academic confinement due to COVID-19?

Using information from the Calculus course, we observed that attention and active participation played particularly key roles, depending on the nature of the class. The badges linked to attention and active participation corresponded to the Flash and Stark badges. Since normality is not a necessary assumption (Nefzger \& Drasgow, 1957) we estimated the correlation between the number of earned attention and active participation badges (Flash and Stark ) per student and their grades in each evaluation period. The results are shown in Table 5.

Table 5

Pearson correlations between the attention badge and midterm (partial) exam scores

\begin{tabular}{llrlrlr}
\hline Grades & Period 1 & $p$ value & Period 2 & $p$ value & Period 3 & $p$ value \\
\hline $\begin{array}{l}\text { Pearson } \\
\text { correlation }\end{array}$ & Flash- & Stark_1 & .240 & Flash- & .646 & Flash- \\
$(N=44)$ & & Stark_2 & & Stark_3 & .555 \\
& & & & & & \\
\hline
\end{tabular}

* Correlation was significant at the 0.01 level (2-tailed)

Table 5 shows a good and positive correlation between attention badges and partial grades in the second and third evaluation periods ( $p$-value $<0.05$ ). Additionally, Table 6 shows the students' opinion of the Calculus class and the reward system. 
Table 6

Opinions of the participants in the calculus class

\begin{tabular}{lcccc}
\multicolumn{1}{c}{ Question } & Totally agree & Agree & Disagree & Totally disagree \\
\hline $\begin{array}{l}\text { Did the reward } \\
\text { system motivate }\end{array}$ & $67 \%$ & $33 \%$ & $0 \%$ & $0 \%$ \\
$\begin{array}{l}\text { you to pay } \\
\text { attention in class? }\end{array}$ & & & & \\
$\begin{array}{l}\text { Did the reward } \\
\text { system motivate }\end{array}$ & $75 \%$ & $20 \%$ & $5 \%$ & $0 \%$ \\
$\begin{array}{l}\text { you to get } \\
\text { involved with the } \\
\text { class? }\end{array}$ & & & & \\
\hline
\end{tabular}

Based on this data, we found that $100 \%$ of the students agreed that the reward system encouraged them to pay attention to the Calculus Class. In comparison, $95 \%$ of them agreed that it motivated them to participate actively. Some students' opinions, when asked why they liked the Flash and Stark badges, provided more specific information about the effects of gamification with a reward system, were as follows:

- $\quad$ Because they make you keep abreast of what the teacher asks.

- Because they motivate you to do homework and attend class.

- Because they encourage participation and harmony with colleagues from other campuses.

- Because through quick questions, you confidently give answers.

- $\quad$ Because they challenge me to think quickly about the answer and be attentive in class (Flash); They helped me attend classes, participate, and help others (Captain America).

- They made me participate more in class.

- Because they commit you to do things well and to improve.

- Because they made me improve my homework and participation in class.

The students' opinions confirmed the statistical results and, at the same time, provided us with a deeper understanding of their feelings about the reward system.

\section{Research question 3: To what extent did gamification with a reward-based system improve students' performance in the academic confinement due to COVID-19?}

All badges that the students earned in the Calculus course were counted and correlated with their grades in the three testing periods (Table 7). This information showed a significant correlation in the three periods; even stronger in the second and third periods when a lockdown occurred. This indicated that gamification based on a reward system had a favourable effect on the students' academic performance in Calculus.

Table 7

Pearson correlations between badges and midterm (partial) grades of calculus course

\begin{tabular}{lcccccc}
\hline Grades & Period 1 & $p$ value & Period 2 & $p$ value & Period 3 & $p$ value \\
\hline $\begin{array}{l}\text { Pearson } \\
\text { correlation }\end{array}$ & Badges 1 & $.435^{*}$ & Badges 2 & $.692^{*}$ & Badges 3 & $.620^{*}$ \\
$(N=44)$ & & & & & & \\
\end{tabular}

* Correlation was significant at the 0.01 level (2-tailed)

For the Development of Transversal Competencies course, since the sample was less than 30, we performed a Spearman correlation test (Table 8). The results show a strong correlation between badges and the final grade, indicating that gamification based on a reward system helped student performance. 
Table 8

Spearman's correlations of Development of Transversal Competencies course

\begin{tabular}{|c|c|c|c|c|}
\hline & & Correlations & Badges & Final grade \\
\hline \multirow[t]{4}{*}{ Spearman's rho } & Badges & $\begin{array}{l}\text { Correlation coefficient } \\
\text { significant (2-tailed) }\end{array}$ & 1.000 & $\begin{array}{l}.806^{*} \\
.000\end{array}$ \\
\hline & & $N$ & & 17 \\
\hline & Final grade & $\begin{array}{l}\text { Correlation coefficient } \\
\text { significant (2-tailed) }\end{array}$ & $\begin{array}{r}.806 * \\
.000\end{array}$ & 1.000 \\
\hline & & $N$ & 17 & \\
\hline
\end{tabular}

The results revealed a strong and positive correlation, showing that gamification using a reward system positively affected student performance. In general, we saw that in these two course scenarios, gamification with a reward system had a positive effect on the grades of students during the confinement of the Covid19 pandemic. Also, the teachers' evaluations showed agreement with the pedagogical resources used in these two courses. This subject received ratings up to 9 on a 0 to 10 scale. The intellectual challenge was an important item in this evaluation, receiving 9.35 in Calculus and 9.0 in the Development of Transversal Competencies course (Table 9).

Table 9

Institutional teachers' evaluation

\begin{tabular}{lrrr}
\hline Course & Intellectual challenge & $\begin{array}{c}\text { Pedagogical } \\
\text { resources }\end{array}$ & $\begin{array}{c}\text { Teacher's interaction in the } \\
\text { academic confinement }\end{array}$ \\
\hline Calculus & 9.35 & 9.35 & 9.05 \\
Development of & 9.0 & 9.25 & 8.94 \\
Transversal & & & \\
Competencies & & & \\
\hline
\end{tabular}

The results of the teacher evaluation report for the Calculus course suggest that both the pedagogical resources and the challenge worked in the new educational model. These results further confirmed the contribution of gamification during Covid-19 conditions. Furthermore, in both courses, students encountered a significant intellectual challenge and successfully undertook the pedagogical resources arried out in class (gamification). It is worth mentioning that the Calculus class required more changes and adaptation of content in the academic confinement context with respect to a face-to-face course, because of the subject's nature.

\section{Discussion}

During the lockdown caused by the Covid-19 pandemic, the students in the two undergraduate courses believed that the gamification strategy motivated them to attend class, participate, and carry out the activities, as verified in Tables 3, 4, and 6 These findings align with Park et al. (2019) and Morschheuser et al. (2019), who found that students perceived it as a pleasant experience to receive a benefit after completing a task or activity. In this sense, our study results proved that gamification applied with a reward system in higher education helped motivate and involve students in an online learning environment under stressful circumstances.

The research also established that the reward system could generate engagement with the course and improve flow. The Flash and Stark badges related to answering spontaneous questions from the teacher and requiring students to be attentive in class, were the favourites for engineering students (see Figure 4). The reward system also led to positive feelings about achievement (Deci \& Ryan, 2008; Lefers \& Birkenkrahe, 2016; Skinner \& Belmont, 1993), generating behavioural, cognitive, and emotional commitment (Fredricks et al., 2004). Thus, we can affirm that the reward system favoured participation and flow in synchronous and asynchronous online activities.

Including badges in a class to recognise students' effort can sustain their attention and positively affect academic performance. The analysed results seen in Table 7 and are complemented by the students' opinions. These findings coincided with the studies (Davis \& McPartland, 2012; Goodyear \& NathanRoberts, 2017; Hamari et al., 2016; Hammedi et al., 2017) where it was found that badges increased 
participation and students' intrinsic and extrinsic motivation by recognising their achievements and abilities. Hence, we can say that including badges in undergraduate classes improved academic performance.

Likewise, the results showed that a reward system improved the performance of students in different areas. Tables 7 and 8 show the strong correlation between the number of badges earned and the participants' performance in both courses. In the teachers' evaluation, the students' opinions were very similar (Table 9). Several authors agree that recognising students for their performance and achievements fosters a positive attitude toward learning and improves it (Rincon-Flores, López-Camacho et al., 2020; Rojas-López \& Rincon-Flores, 2018; Santos-Guevara \& Rincon-Flores, 2020; Smiderle et al., 2020). Consequently, we propose that a reward system that recognises cognitive aspects and skills, attitudes, and values can positively affect academic performance.

Several anthropological research investigations found that games were an intrinsic activity in the life of a human being of any age and gender (Santos-Guevara \& Rincon-Flores, 2021; Smiderle et al., 2020; Stefani et al., 2014). Therefore, gamification as part of educational strategy can transform learning environments into more enjoyable processes, as a result of the recognition of the student, both in the cognitive aspects, attitudes, and values, as well as the atmosphere of constructive competition generated by the reward system. We also highlight an interesting finding that confirmed how gamification is seen as interactive. In the Calculus class, badges were given almost instantaneously when students earned them. In contrast, in the other course, badges were given after one or two sessions, when students' assignments were graded, or the group voting was completed. We observed a slight but significant difference in the teacher's evaluation for interactivity. Even though different factors, unrelated to gamification, affected this evaluation, we recommend researching this correlation in the future.

Finally, the research results showed that gamification with a reward system boosted the participants' attention, active learning, and performance, making the learning environment more pleasant and exciting. Thus, these results are optimistic and promising in a confined environment that generated stress, isolation, and depression among some students (Arnove, 2020; Daniel, 2020; APA, 2020). Continuous participant recognition helped their emotional states (Korving et al., 2016 Thomas \& Rogers, 2020; Zhao, 2020), particularly in learning environments developed during a global health crisis.

\section{Conclusions}

The COVID-19 pandemic forced us to migrate traditional courses with little interaction to the virtual teaching. Here, gamification played a crucial role in motivating students and increasing their participation. This model embraced gamification in education. Student require significant learning, which can be obtained through gamification mechanics. After analysing students' efforts, participation, and improvement in academic performance, we consider this experience was successful. The results in both courses indicated that gamification improved the learning process in different settings and contexts.

Motivation is crucial in education; however, its necessity is even more urgent in a lockdown situation because it causes students to vary in their emotional and mental states. Gamification can create a dynamic learning and safe environment that motivates, boosts autonomy and flexibility, and provides frequent positive stimuli. It can also reduce frustration caused by sudden changes, because Covid-10 pandemic, and a need to improve students' emotional state, thus, transforming education beyond the mere awarding of academic credits.

Interactions are affected if the students see the leaderboard infrequently used, so we recommend that teachers take the time to update the leaderboard as frequently as possible to show student progress. Also, we suggest establishing a maximum number of badges in each class, depending on the nature of the course, to motivate all students to participate. The education designer must consider the reward system mechanics carefully in the course design.

The main objective of the gamification proposal in this study, which focused on students' attention, active participation, and performance in the two undergraduate-level courses, was achieved despite the sudden migration from a face-to-face teaching model to a virtual one. Gamification is of particular interest in these pandemic times because people need more digital social interactions to counteract the loss of social contact 
in the university classroom. Furthermore, this research shows that gamification is a teaching strategy that can potentially be applied in any discipline and learning environment.

\section{Acknowledgment}

The authors acknowledge the technical support of Writing Lab, Institute for the Future of Education, Tecnologico de Monterrey, Mexico, in the production of this work.

\section{References}

Admiraal, W., Huizenga, J., Akkerman, S. \& ten Dam, G. (2011). The concept of flow in collaborative game-based learning. Computers \& Human Behavior, 27(3), 1185-1194. https://doi.org/10.1016/j.chb.2010.12.013

Aji, C. A., \& Khan, M. J. (2019). The impact of active learning on students' academic performance. Open Journal Social Sciences, 7(3), 204-211. https://doi.org/10.4236/jss.2019.73017

Alsawaier, R. S. (2018). The effect of gamification on motivation and engagement. International Journal of Information and Learning Technology, 35, 56-79. https://doi.org/10.1108/IJILT-02-2017-0009

American Psychological Association (2020). Human behavior in the time of COVID-19: Learning from psychological science. https://www.psych ologi calsc ience .org/obser ver/human -behav ior-inthetime-of-covid -19

Amso, D, \& Scerif, G. (2015). The attentive brain: Insights from developmental cognitive neuroscience. Nature Reviews Neuroscience, 16(10), 606-619. https://doi.org/10.1038/nrn4025

Arnove, R. (2020). Imagining what education can be post-COVID-19. Prospect, 49(1-2), 43-46. https://doi.org/10.1007/s11125-020-09474-1

Borras-Gene, O., Martinez-Nuñez, M., \& Fidalgo-Blanco, Á. (2016). New challenges for the motivation and learning in engineering education using gamification in MOOC. International Journal of Engineering Education, 32, 501-512. http://www.scopus.com/inward/record.url?eid=2-s2.084959358012\&partnerID=tZOtx3y1

Buchem, I., Merceron, A., Kreutel, J., Haesner, M., \& Steinert, A. (2015). Gamification designs in wearable enhanced learning for healthy aging. Proceedings of 2015 International Conference on Interactive Mobile Communication Technologies and Learning, IMCL 2015, 9-15. Institute of Electrical and Electronics Engineers Inc. https://doi.org/10.1109/IMCTL.2015.7359545

Caponetto, I., Earp, J., \& Ott, M. (2014). Gamification and education: A literature review. Proceedings of the European Conference on Games Based Learning, 1, 50-57. http://www.scopus.com/inward/record.url?eid=2-s2.0-84923559781\&partnerID=tZOtx3y1

Creswell, J. W. (2007). Qualitative inquiry research design. Choosing among five approaches (2nd ed.). Sage.

Creswell, J. W., Plano Clark, V. L., Guttmann, M. L., \& Hanson, E. E. (2003). Advanced mixed methods research design. In A. Tashakkori, \& C. Teddlie (Eds.), Handbook of mixed methods in social and behavioral research (pp. 209-240). Sage.

Csikszentmihalyi, M. (1990). Flow: The psychology of optimal experience. Harper Perennial.

Daniel, S. J. (2020). Education and the COVID-19 pandemic. Prospects, 49(1-2), 91-96. https://doi.org/10.1007/s11125-020-09464-3

Davis, M., \& McPartland, J. (2012). High school reform and student engagement. In S. Christenson, A. Reschly, \& C. Wylie (Eds.), Handbook of research on student engagement (pp. 515-539). Springer. https://doi.org/10.1007/978-1-4614-2018-7_25

Deci, E. L. \& Ryan, R. M. (2008). Facilitating optimal motivation and psychological well-being across life's domains. Canadian Psychology, 49, 14-23. https://doi.org/10.1037/0708-5591.49.1.14

Deterding, S. (2015). The lens of intrinsic skill atoms: A method for gameful design. Human-Computer Interaction, 30(3-4), 294-335. https://doi.org/10.1080/07370024.2014.993471

Dichev, C., \& Dicheva, D. (2017). Gamifying education: What is known, what is believed and what remains uncertain: A critical review. International Journal of Educational Technology in Higher Education, 14(9). https://doi.org/10.1186/s41239-017-0042-5

Domínguez, A., Saenz-De-Navarrete, J., de-Marcos, L., Fernández-Sanz, L., Pagéx, C., \& MartínezHerraíz, J. (2013). Gamifying learning experiences: Practical implications and outcomes. Computers \& Education, 63, 380-392. https://doi.org/10.1016/j.compedu.2012.12.020 
Fredricks, J., Blumenfeld, P., \& Paris, A. (2004). School engagement: The potential of the concept, state of the evidence. Review of Educational Research, 74, 59-109.

https://doi.org/10.3102/00346543074001059

Freeman, S., Eddy, S. L., McDonough, M., Smith, M. K., Okoroafor, N., Jordt, H., \& Wenderoth, M. P. (2014). Active learning increases student performance in science, engineering, and mathematics. Proceedings of the National Academy of Sciences of the United States of America, 111(23), 8410-8415. https://doi.org/10.1073/pnas.1319030111.

Freudmann, E. A., \& Bakamistos, Y. (2014). The role of gamification in non-profit marketing: An information processing account. Procedia. Social Behavior Sciences, 148, 567-572. https://doi.org/10.1016/j.sbspro.2014.07.081

Frost, R. D., Matta, V., \& MacIvor, E. (2015). Assessing the efficacy of incorporating game dynamics in a learning management system. Journal of Information Systems Education, 26, 59-70. https://aisel.aisnet.org/jise/vol26/iss1/6

Garett, R., \& Young, S. D. (2019). Health care gamification: A study of game mechanics and elements. Technology, Knowledge and Learning, 24(3), 341-353. https://doi.org/10.1007/s10758-018-9353-4

Gomez-Chacón, I. (2000). Matemática emocional: Los afectos en el aprendizaje matemático (Emotional calculus: Affections in math learning). Narcea.

Goodyear M, \& Nathan-Roberts, D. (2017). Gamification and the design of badges in relation to educational achievement. In Proceedings of the Human Factors and Ergonomics Society 61, Austin, TX. 1229-1233. https://doi.org/10.1177/1541931213601789

Gruman, J., Holmes-Rovner, M., French, M. E., \& Jeffres, D. (2010). From patient education to patient engagement: Implications for the field of patient education. Patient Education and Counseling, 78(3), 350-356. https://doi.org/10.1016/j.pec.2010.02.002

Hamari, J., \& Koivisto, J. (2015). Working out for likes: An empirical study on social influence in exercise gamification. Computers \& Human Behavior, 50, 333-347. https://doi.org/10.1016/j.chb.2015.04.018

Hamari, J., Shernoff, D. J., Rowe, E., Coller, B., \& Asbell-Clarke, J. (2016). Challenging games help students learn: An empirical study on engagement, flow and immersion in game-based learning. Computers \& Human Behavior, 54, 170-179. https://doi.org/10.1016/j.chb.2015.07.045

Hammedi, W., Leclerq, T., \& Van Riel, A. C. R. (2017). The use of gamification mechanics to increase employee and user engagement in participative healthcare services. Journal of Service Management, 28(4), 640-661. https://doi.org/10.1108/JOSM-04-2016-0116

Hanus M. D., \& Fox, J. (2015). Assessing the effects of gamification in the classroom: A longitudinal study on intrinsic motivation, social comparison, satisfaction, effort, and academic performance. Computers \& Education, 80, 152-161. https://doi.org/10.1016/j.compedu.2014.08.019

Hassan, L., \& Hamari, J. (2020). Gameful civic engagement: A review of the literature on gamification of e-participation. Government Information Quarterly, 37(3), 1-21. https://doi.org/10.1016/j.giq.2020.101461

Heninger, W. G., Smith, S. D. \& Wood, D. A. (2019). Reward type and performance: An examination of organizational wellness. Management Accounting Research, 44, 1-11. https://doi.org/10.1016/j.mar.2019.02.001

Herzig, P., Ameling, M., Wolf, B., \& Schill, A. (2015). Implementing gamification: Requirements and gamification platforms. In T. Reiners, \& C. L. Wood (Eds.), Gamification in education and business (pp. 431-450). Springer International Publishing. https://doi.org/10.1007/978-3-319-10208-5 22

Hou. H-T., \& Li, M-Ch. (2014). Evaluating multiple aspects of a digital educational problem-solvingbased adventure game. Computers \& Human Behavior, 30, 29-38. https://doi.org/10.1016/j.chb.2013.07.052

Iain, S., Robertson, J., Manches, A., \& Rajendran, G. (2019). BrainQuest: The use of motivational design theories to create a cognitive training game supporting hot executive function. International Journal of Human Computer Studies, 127, 124-149. https://doi.org/10.1016/j.ijhcs.2018.08.004

Jin. L., Zhang, K., \& Lu, J. (2016). Towards understanding the gamification upon users' scores in a location-based social network. Multimedia Tools and Applications, 75(15), 8895-8919. https://doi.org/10.1007/s11042-014-2317-3

Kocadere, S. A., \& Çağlar, Ş. (2018). Gamification from player type perspective: A case study. Educational Technology \& Society, 21(3), 12-22. https://www.jstor.org/stable/26458503

Korving, H., Hernández, M., \& De Groot, E. (2016). Look at me and pay attention! A study on the relation between visibility and attention in web lectures. Computers \& Education, 94, 151-161. https://doi.org/10.1016/j.compedu.2015.11.011 
Kwiatek, P., \& Thanasi-Boçe, M. (2019). Loyalty program activity: Make B2B customers buy more. Marketing Intelligence \& Planning, 37(5), 542-554. https://doi.org/10.1108/MIP-06-2018-0193

Kyewski, E., \& Krämer, N. (2018). To gamify or not to gamify? An experimental field study of the influence of badges on motivation, activity, and performance in an online learning course. Computers \& Education, 118, 25-37. https://doi.org/10.1016/j.compedu.2017.11.006

Laato, S., Islam, A. K. M. N., \& Laine, T. H. (2020). Did location-based games motivate players to socialize during COVID-19? Telematics and Informatics54, 1-12. https://doi.org/10.1016/j.tele.2020.101458

Lagubeau, G., Tecpan, S., \& Hernández, C. (2019). Active learning reduces academic risk of students with non-formal reasoning skills. Evidence from an introductory physics massive course in a Chilean public university. Physical Review Physics Education Research, 16(2), 1-6. https://doi.org/10.1103/PhysRevPhysEducRes.16.023101

Lee J, \& Hammer J. (2011). Gamification in education: What, how, why bother? Academic Exchange Quarterly, 15(2), 1-5. https://www.researchgate.net/publication/258697764

Lefers, B., \& Birkenkrahe, M. (2016). How can educators with limited resources gamify their classes? A design-based approach. Proceedings of the European Conference on Games-Based Learning, Janua, 354-363. https://www.mendeley.com/catalogue/1944dce0-7543-3412-a2fa$\underline{5 b 4 c 9 e 3 f 2 c b b / \text { ?utm source }=\text { desktop }}$

Looyestyn, J., Kernot, J., Boshoff, K., Ryan, J., Edney, S., \& Maher, C. (2017). Does gamification increase engagement with online programs? A systematic review. PloS ONE, 12(3) 1-20. https://doi.org/10.1371/journal.pone.0173403

Magaña-Valladares, L., González-Robledo, M., Rosas-Magallanes, C., Mejía-Arias, M., Arreola-Ornelas, H., \& Knaul, F. (2018). Training primary health professionals in breast cancer prevention: Evidence and experience from Mexico. Journal of Cancer Education, 33, 160-166. https://doi.org/10.1007/s13187-016-1065-7

Morschheuser, B., Hamari, J., \& Maedche, A. (2019). When do people contribute more? A field experiment on gamification of crowdsourcing. International Journal of Human-Computer Studies Cooperation orCcompetition, 127, 7-24. https://doi.org/10.1016/j.ijhcs.2018.10.001

Nefzger, M. D., \& Drasgow, J. (1957). The needless assumption of normality in Pearson's r. American Psychologist, 12(10), 623-625. https://doi.org/10.1037/h0048216

Observatory on Educational Innovation (2020). Tec de Monterrey crea el modelo flexible y digital para la continuidad académica de más de 90 mil alumnos. https://observatorio.tec.mx/edu-news/modeloflexible-digital-tec-de-monterrey

Park, J., Kim, S., Kim, A., \& Yi, M. Y. (2019). Learning to be better at the game: Performance vs completion contingent reward for game-based learning. Computers \& Education, 139, 1-15. https://doi.org/10.1016/j.compedu.2019.04.016

Plangger, K., Campbell, C., Robson, K., \& Montecchi, M. (in press). Little rewards, big changes: Using exercise analytics to motivate sustainable changes in physical activity. Information \& Management. https://doi.org/10.1016/j.im.2019.103216

Posner, M. I., Snyder, C. R., \& Davidson, B. J. (1980). Attention and the detection of signals. Journal of Experimental Psychology: General, 109(2), 160-174. https://doi.org/10.1037/0096-3445.109.2.160

Rincon-Flores, E. G., Gallardo, K., \& de la Fuente, J. (2018). Strengthening an educational innovation strategy: Processes to improve gamification in a calculus course through performance assessment and meta-evaluation. International Electronic Journal of Calculus Education, 13, 1-11. https://doi.org/10.12973/iejme/2692

Rincon-Flores, E. G., Lopez-Camacho, E., \& Lopez, O. O. (2020). Engaging a calculus course with telepresence through gamification. Proceedings of the IEEE Global Engineering Education Conference, Porto, Portugal. 1055-1059. https://doi.org/10.1109/EDUCON45650.2020.9125163

Rincon-Flores, E. G., Mena, J., Ramírez, \& Ramírez-Montoya, M. (2020). The use of gamification in a MOOC about energy: Effects and predictive models for participants' learning. Australasian Journal of Educational Technology, 32(2), 43-59. https://doi.org/10.14742/ajet.4818

Robson, K., Plangger, K., Kietzmann, J. H., McCarthy, I., \& Pitt, L. (2015). Is it all a game? Understanding the principles of gamification. Business Horizons, 58(4), 411-420. https://doi.org/10.1016/j.bushor.2015.03.006

Rodríguez, F., \& Santiago, R. (2015). Gamificación: cómo motivar a tu alumnado y mejorar el clima en el aula (Gamification: How to motivate your students and improve the climate in the classroom). Oceano. 
Rojas-López, A., \& Rincon-Flores, E. G. (2018). Gamification as learning scenario in programming course of higher education. In P. Zaphiris, \& A. Ioannou (Eds.), Learning and collaboration technologies: Learning and teaching. Lecture notes in computer science (Vol. 10925, pp. 200-210). Springer. https://doi.org/10.1007/978-3-319-91152-6_16

Rojas-López, A., Rincon-Flores, E. G., Mena, J., García-Peñalvo, F. \& Ramírez-Montoya, S. (2019). Engagement in the course of programming in higher education through the use of gamification. Universal Access Information Society, 18, 583-597. https://doi.org/10.1007/s10209-019-00680-z

Sailer, M., Hence, J. U., Mayr, S. K., \& Mandl, H. (2017). How gamification motivates: An experimental study of the effects of specific game design elements on psychological need satisfaction. Computers \& Human Behavior, 69, 371-380. https://doi.org/10.1016/j.chb.2016.12.033

Santos-Guevara, B. N., \& Rincon-Flores, E. G. (2020). Work in progress: Engaging professional competencies through gamification. Proceedings of the IEEE Global Engineering Education Conference, Porto, Portugal. 1160-1163. https://doi.org/10.1109/EDUCON45650.2020.9125332

Santos-Guevara, B. N., \& Rincon-Flores, E. G. (2021). Avatars and badges, are there differences between genders? Proceedings of the IEEE Global Engineering Education Conference, Vienna, Austria. 334338. https://doi.org/10.1109/EDUCON46332.2021.9454126.

Saputro, R. E., Salam, S., Zakaria, M. H., \& Septiadi, A. D. (2019). Towards personalization to support learners' motivation on gamified MOOC platform. Journal of Physics: Conference Series, 1201, 1-8. https://doi.org/10.1088/1742-6596/1201/1/012031

Schöbel, S., \& Söllner, M. (2014). Does the winner take it all? Gaming anion design. Proceedings of the European Conference on Information Systems, Tel Aviv, 3102-3114. https://www.mendeley.com/catalogue/f2d51ade-43de-342f-a30dd153693acc38/?utm_source=desktop\&utm_medium=1.19.8\&utm_campaign=open_catalog\&userDoc umentId=\%7Ba86e0bc1-ce5a-46ca-bc16-fb7b547be72d\%7D

Skinner, E., \& Belmont, M. J. (1993). Motivation in the classroom: Reciprocal effects of teacher behavior and student engagement across the school year. Journal of Educational Psychology, 85(4), 571-581. https://doi.org/10.1037/0022-0663.85.4.571

Smeddinck, J. D., Herrlich, M., Wang, X., Zhang, G., \& Malaka, R. (2019). Work hard, play hard: How linking rewards in games to prior exercise performance improves motivation and exercise intensity. Entertainment Computing, 29, 20-30. https://doi.org/10.1016/j.entcom.2018.10.001

Smiderle, R., Rigo, S. J., Marques, L. B., de Miranda C., J. A. P., \& Jaques, P. (2020). The impact of gamification on students' learning, engagement and behavior based on their personality traits. Smart Learning Environments, 7(3). https://doi.org/10.1186/s40561-019-0098-x

Stefani, G., Andrés, L., \& Oanes, E. (2014). Transformaciones lúdicas. Un estudio preliminar sobre tipos de juego y espacios lúdicos. Interdisciplinaria, 31, 39-55. https://www.redalyc.org/articulo.oa?id=18031545003

Surendeleg, G., Murwa, V., Yun, H. K., \& Kim, Y. S. (2014). The role of gamification in education-a literature review. Contemporary Engineering Sciences, 7(29),1609-1616. https://doi.org/10.12988/ces.2014.411217

Tan, M., \& Hew, K. F. (2016). Incorporating meaningful gamification in a blended learning research methods class: Examining student learning, engagement, and affective outcomes. Australasian Journal of Educational Technology, 32, 19-34. https://doi.org/10.14742/ajet.2232

Tharayil S., Borrego, M., Prince, M., Nguyen, K. A, Shekhar, P., Finelli, C., \& Waters, C. (2018). Strategies to mitigate student resistance to active learning. International Journal of STEM Education, 5. https://doi.org/10.1186/s40594-018-0102-y

Thomas, M. S. C., \& Rogers, C. (2020). Education, the science of learning, and the COVID-19 crisis. Prospects, 49, 87-90. https://doi.org/10.1007/s11125-020-09468-Z

Topîrceanu, A. (2017). Gamified learning: A role-playing approach to increase student in-class motivation. Procedia Computer Sciences, 112, 41-50. https://doi.org/10.1016/j.procs.2017.08.017

Tsai, M-J., Huang, L-J., Hou, H-T., \& Hsu, Ch-Y. (2016). Visual behavior, flow and achievement in game-based learning. Computers \& Education, 98, 115-129. https://doi.org/10.1016/j.compedu.2016.03.011

Werbach, K., \& Hunter, D. (2012). For the win: How game thinking can revolutionize your business. Wharton Digital Press.

Wu, Y. L. (2018). Gamification design: A comparison of four m-learning courses. Innovations in Education and Teaching International, 55(4), 470-478. https://doi.org/10.1080/14703297.2016.1250662 
Xin O. W., Zuo, L., Iida H., \& Aziz, N. (2018) Gamification effect of loyalty program and its assessment using game refinement measure: Case study on Starbucks. In R. Alfred., H. Iida, A., Ag. Ibrahim, \& Y. Lim (Eds), Computational Science and Technology. ICCST 2017. Lecture Notes in Electrical Engineering (Vol. 488). Springer. https://doi.org/10.1007/978-981-10-8276-4_16

Zhao, Y. (2020). COVID-19 as a catalyst for educational change. Prospects, 49(1-2), 29-33. https://doi.org/10.1007/s11125-020-09477-y

Zimmerling, E., Höllig, C. E., Sandner, P. G., \& Welpe, I. M. (2019). Exploring the influence of common game elements on ideation output and motivation. Journal of Business Research, 94, 302-312. https://doi.org/10.1016/j.jbusres.2018.02.030

Corresponding author: Elvira G. Rincon-Flores, elvira.rincon@tec.mx

Copyright: Articles published in the Australasian Journal of Educational Technology (AJET) are available under Creative Commons Attribution Non-Commercial No Derivatives Licence (CC BY-NCND 4.0). Authors retain copyright in their work and grant AJET right of first publication under CC BYNC-ND 4.0.

Please cite as: Rincon-Flores, E. G., \& Santos-Guevara, B. N. (2021). Gamification during Covid-19: Promoting active learning and motivation in higher education. Australasian Journal of Educational Technology, 37(5), 43-60. https://doi.org/10.14742/ajet.7157 